\title{
シンポジウム
}

\section{1．認知症の病態解明の進歩一認知症と蛋白異常による分類と病態 司会者のことば}

\author{
司会 中島 健二 1) \\ 司会 山田 正仁 ${ }^{2)}$
}

認知症には多くの原因疾患があるが, Alzheimer病 (Alzheimer's disease : AD), Lewy 小体型認知症 (dementia with Lewy bodies : DLB), 前頭側頭葉変性症 (frontotemporal lobar degeneration：FTLD)などの神経変性性の認知 症が多くを占める。しかし，それらの神経変性 性認知症の病態機序はいまだに不明である。最 近の分子生物学的研究を始めとした基礎研究の 発展により, $\mathrm{AD}$ ・DLB・FTLDなどの認知症の 原因に関連すると考えられる蛋白が明らかにさ れてきた。 これらの蛋白にアプローチしていく 研究は, 認知症の根治的治療法 (disease modifying therapy）の開発につながるものと期待され る.また,これらの蛋白の解析によりバイオマー カーの開発も進められると考えられ, 認知症疾 患の早期診断への発展も期待されている.

本シンポジウムでは, 蛋白からみた認知症へ のアプローチ, 認知症における蛋白異常に関す
る研究の進歩について示して頂く. 認知症にお ける病態的位置づけの解明が進んできている, アミロイド $\beta$ 蛋白, $\alpha$ シヌクレイン, タウ蛋白, TDP-43 について解説して頂く.

一方, 本シンポジウムのプログラムを検討し ていた 2009 年に, 家族性筋萎縮性側索硬化症に おけるfused in sarcoma/translated in liposarcoma (FUS/TLS) の遺伝子変異が報告され，こ のFUS/TLSがFTLDに関連する可能性が指摘さ れた。しかし，関連性は推定されたもののまだ 必ずしも明確ではなかったところから，“概説” としてFUS/TLSも含めて認知症に関連する可能 性のある蛋白を網羅して議論することとして“概 説”の講演を予定した.

本シンポジウムを通して, 認知症に関与する これらの蛋白に関する研究の現状と今後の展望 を把握し, 認知症研究・医療の課題と方向性を 明らかにしていくことができるものと期待する.

1) 鳥取大学脳神経医科学講座脳神経内科学分野，2）金沢大学大学院脳老化・神経病態学（神経内科）

108th Scientific Meeting of the Japanese Society of Internal Medicine:Symposium:1. Progress in dementia research-Dementia disorders and protein ; Introduction.

Kenji Nakashima ${ }^{1)}$ and Masahito Yamada ${ }^{2)}:{ }^{1}$ Division of Neurology, Department of Brain and Neurosciences, School of Medicine, Feculty of Medicine, Tottori University, Japan and ${ }^{2}$ Department of Neurology and Neurobiology of Aging, Kanazawa University Graduate School of Medical Science, Japan. 